\title{
Tiefere Prämien für Sie und Ihre Mitarbeitenden
}
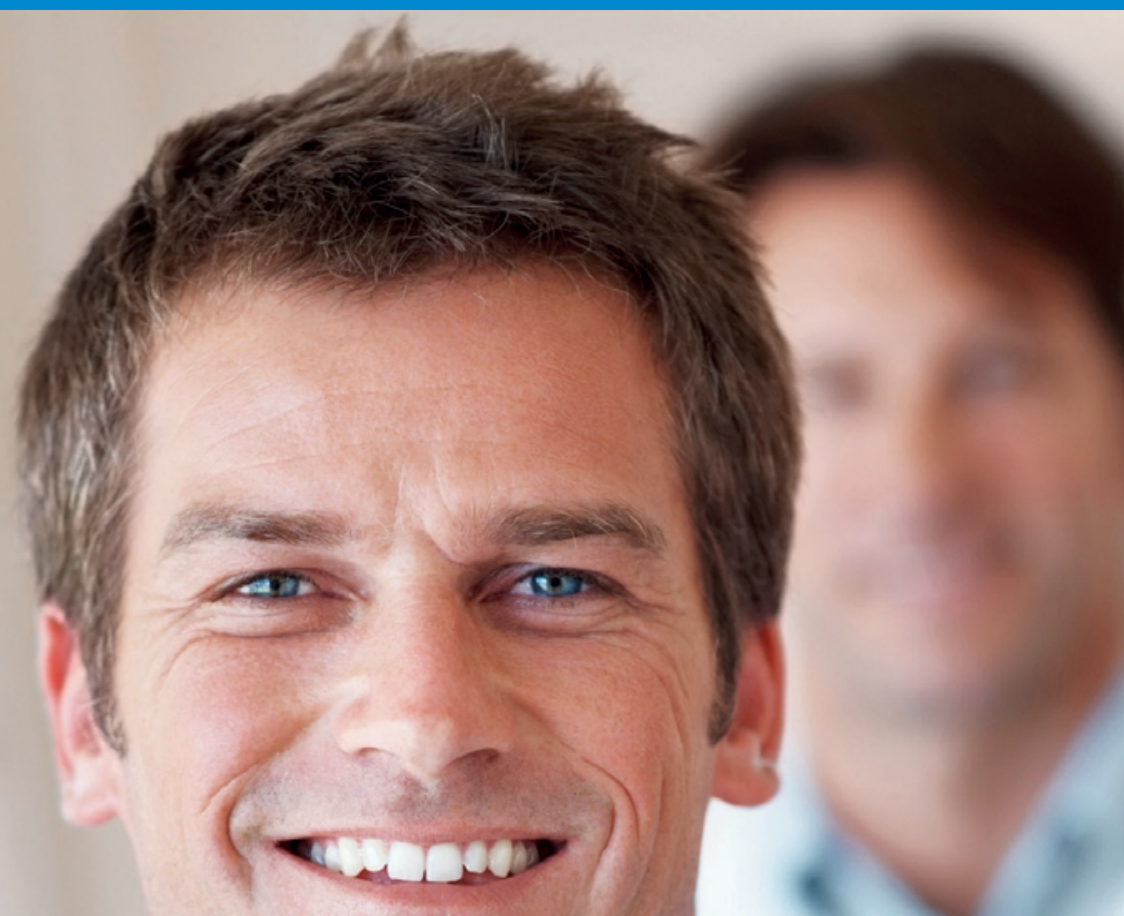